\title{
Hak Pasien dan Kewajiban Apoteker dalam Memberikan Pelayanan Informasi Obat di Apotek
}

\author{
Yoga Fitra Ananta \\ Institut Ilmu Kesehatan STRADA Indonesia \\ Email : yogaananta046@gmail.com
}

\begin{abstract}
Abstrak
Hukum kesehatan semakin dikenal oleh publik, sedangkan pemberian obat yang tidak rasional masih sering dilakukan. Hubungan yang baik antara pasien dengan tenaga kesehatan memperbesar tercapainya pengobatan yang diharapkan. Dalam pembahasan kali ini mengenai hak-hak yang dimiliki oleh pasien serta kewajiban seorang Apoteker maupun Asisten Farmasi atas pemberian

informasi obat-obatan yang relevan berdasarkan pertimbangan dari berbagai pihak terkait.

Penyelenggaraan upaya kesehatan harus dilakukan oleh tenaga kesehatan yang bertanggung jawab, yang memiliki etik dan moral yang tinggi, keahlian, dan kewenangan yang secara terus menerus harus ditingkatkan mutunya melalui pendidikan dan pelatihan berkelanjutan, sertifikasi, registrasi, perizinan, serta pembinaan, pengawasan, dan pemantauan agar penyelenggaraan upaya kesehatan memenuhi rasa keadilan dan perikemanusiaan serta sesuai dengan perkembangan ilmu pengetahuan dan teknologi kesehatan. Peran apoteker dalam pemberdayaan konsumen atas informasi obat dilaksanakan pada pengobatan swa-medikasi di apotek dan di rumah sakit apoteker memberdayakan konsumen atas informasi obat dengan cara memberikan informasi, konseling, promosi dan edukasi.
\end{abstract}

\section{Latar Belakang}

Tenaga Kesehatan adalah setiap orang yang mengabdikan diri dalam bidang kesehatan serta memiliki pengetahuan dan/atau ketrampilan melalui pendidikan di bidang kesehatan yang untuk jenis tertentu memerlukan kewenangan untuk melakukan upaya kesehatan. Sesuai dengan Undangundang tenaga kesehatan bahwa tenaga kesehatan memiliki peranan penting untuk meningkatkan kualitas pelayanan kesehatan yang maksimal kepada masyarakat agar masyarakat mampu untuk meningkatkan kesadaran, kemauan, dan kemampuan hidup sehat sehingga akan terwujud derajat kesehatan yang setinggi-tingginya sebagai investasi bagi pembangunan sumber daya manusia yang produktif secara sosial dan ekonomi serta sebagai salah satu unsur kesejahteraan umum sebagaimana dimaksud dalam Pembukaan Undang-Undang Dasar Negara Republik Indonesia Tahun 1945.

Dalam praktek kefarmasian, apoteker memiliki tugas untuk pengendalian sediaan farmasi, pengadaan, penyimpanan, pendistribusian obat hingga obat sampai kepada pasien yaitu saat pelayanan obat atas resep dokter serta pelayanan informasi obat. Pasien adalah setiap orang yang melakukan konsultasi masalah kesehatannya untuk memperoleh pelayanan kesehatan yang diperlukan baik secara langsung maupun tidak langsung.

Pelayanan kesehatan ditengah dinamika moderenisasi kehidupan masyarakat di Indonesia yang didalamnya semakin meningkatnya kesadaran hukum masyrakat, menjadikan profesi tenaga kesehatan harus mempersiapkan diri secara maksimal dan proporsional. Sebagai perwujudan derajat tenaga kesehatan secara optimal agar serasi dan selaras denga tujuan pembangunan kesehatan, diperlukan suatu keseimbangan antara hak dan kewajiban pada pemberi jasa pelayanan kesehatan dengan kepentingan pihak-pihak. Tenaga kesehatan merupakan unsur yang sangat strategis ataupun utama dalam mewujudkan pelayanan kesehatan yang optimal, aman, tertib dan profesional, yang berlangsung setiap waktu dan berkesinambungan. 
Pengaturan standar pelayanan kefarmasian dimaksudkan untuk meningkatkan mutu pelayanan kefarmasian, menjamin kepastian hukum bagi tenaga kefarmasian dan melindungi pasien dari penggunaan obat yang tidak rasional dalam rangka keselamatan pasien (patient safety). Bertujuan agar tidak terjadinya kesalahan dalam pemberian obat dan informasi kepada pasien sebab maraknya kesalahan dalam pemberian obat yang tidak rasional.

Informasi terkait obat penting bagi konsumen. Dengan mengetahui secara mendetail informasi, maka konsumen dapat mengetahui dengan pasti tujuan penggunaan dan hal-hal lain yang terkait dengan obat yang dikonsumsi. Obat akan berfungsi sebagaimana mestinya apabila digunakan sesuai dengan tujuan dan cara penggunaan.

\section{Kasus/Masalah}

Karena masih banyak terjadi kesalahan dalam pengobatan dan terdapat laporan kasus setiap tahun bahkan setiap bulannya. Berbagai kasus terjadi berkaitan dengan kesalahan administrasi pengobatan yang tidak disengaja saat pemberian dan saat perawatan hingga pemberian informasi obat yang tidak rasional salah satunya kasus bapak IU. Awalnya Tn IU merasakan mata kiri perih karena terkena sabun kemudian membasuh mata dengan air namun tidak membaik, lalu pasien membeli tetes mata insto, namun tidak memberikan efek pasien pun berinisiatif untuk pergi ke apotek membeli obat mata yang termasuk obat keras dan harus menggunakan resep dokter namun pasien tetap meminta obat tersebut hingga akhirnya diberikan kepada pasien namun tidak membaca aturan pakai yang seharusnya hanya 3 tetes setiap 6 jam sehingga setelah menggunakan obat tersebut mata pasien malah semakin perih, dan saat obat diteteskan terasa panas. Akhirnya pasien pergi ke Puskesmas dan memberitahukan kepada dokter mengenai obat yang digunakan hasilnya kornea mata pasien mengalami kerusakan. Sedangkan masih adanya pemberian obat kepada pasien yang tidak rasional terkait dengan jumlah obat yang diresepkan berlebihan maupun informasi tentang obat.
Untuk itu disini akan membahas mengenai :

hal-hal apa saja yang harus dilakukan agar terwujudnya pelayanan pengobatan yang baik khususnya dalam informasi obat di apotek?

Hak-hak pasien dalam memperoleh pelayanan kesehatan?

Dan kewajiban seorang Apoteker dan Farmasis.

\section{Tinjauan Pustaka}

Dalam Permenkes No.73 Tahun 2016 tentang Standar Pelayanan Kefarmasian di Apotek menjelaskan bahwa Standar Pelayanan Kefarmasian adalah tolak ukur yang dipergunakan sebagai pedoman bagi tenaga kefarmasian dalam menyelenggarakan pelayanan kefarmasian. Sedangkan Pelayanan Kefarmasian adalah suatu pelayanan langsung dan bertanggung jawab kepada pasien yang berkaitan dengan sediaan farmasi dengan maksud mencapai hasil yang pasti untuk meningkatkan mutu kehidupan pasien.

Pekerjaan kefarmasian menurut UndangUndang Kesehatan No. 36 Tahun 2009 yaitu meliputi pembuatan termasuk pengendalian mutu sediaan farmasi, pengamanan, pengadaan, penyimpanan dan pendistribusian obat, pelayanan obat atas resep dokter, pelayanan informasi obat serta pengembangan obat, bahan obat dan obat tradisional harus dilakukan oleh tenaga kesehatan yang mempunyai keahlian dan kewenangan sesuai dengan ketentuan peraturan perundangundangan. Menurut Permenkes No.73 Tahun 2016 tentang Standar Pelayanan Kefarmasian di Apotek pengertian Apoteker adalah sarjana farmasi yang telah lulus sebagai apoteker dan telah mengucapkan sumpah jabatan apoteker, sedangkan Tenaga Teknis Kefarmasian adalah tenaga yang membantu apoteker dalam menjalani Pekerjaan Kefarmasian, yang terdiri atas Sarjana Farmasi, Ahli Madya Farmasi, dan Analis Farmasi.

Medication eror merupakan kejadian yang tidak bisa dihindarkan dalam pemberian obat yang tidak rasional. Pengertian mediaction eror ( kesalahan pelayanan obat ) merupakan setiap kejadian yang dapat dihindari yang 
menyebabakan atau berakibat pada pelayanan obat yang tidak tepat atau membahayakan pasien. Sementara obat berada dalam pengawasan tenaga kesehatan atau pasien. Disinipula dijelaskan bahwa medication error dapat terjadi pada tahap prescribbing (peresaparn), dispensing (penyiapan), dan drug administration (pemberian obat) dimana apabila terjadi kesalahan salah satu dari hal tersebut dapat menimbulkan kesalahah pada tahap selanjutnya. Dalam pemberian obat yang tepat perlu memperhatikan lima tepat (five rights) yang terdiri atas tepat pasien (right client), tepat obat (right drug), tepat dosis (right dose),tepat waktu (right time), dan tepat rate (right rute). Medication error atau kesalahan dalam pelayanan obat dapat dihindari dimana yang paling penting adalah memahami bagaimana caranya dalam meminimalisir dan menghindari kesalahan medication error. Sistem pengamanan pelayanan obat di apotek pada umumnya menerapkan pengecekan ulang baik oleh farmasis maupun asisten farmasis kepala. Bila terjadi Medication Error hal yang dilakukan sebagai berikut:

1. Bila terjadi kesalahan dalam peracikan maka dilakukan diskusi antara farmasis, asisten farmasis dan petugas lain, dijelaskan mengenai kesalahan yang terjadi.

2. Bila terjadi kesalahan dan obat telah diserahkan pada pasien maka asisten farmasis melapor kepada farmasis, bila diperlukan menghubungi dokter

3. Bila terjadi kesalahan pada peresepan atau langsung menghubungi pasien dan menjelaskan mengenai kesalahan dan menukar obat dengan yang benar.

Peran farmasis sangat besar dalam pencegahan kesalahan pelayanan obat dalam peresepan, pada penerimaan resep farmasis harus bekerja ekstra hati-hati dalam menerjemahkan perintah dokter kedalam pelayanan pemberian obat.

Penggunaan obat yang rasional adalah pola pemberian obat yang tepat yaitu pemilihan obat yang sesuai dengan diagnosis penyakitnya, tepat konsumsinya, tepat dosisnya, tepat jangka waktu pemberiannya, dan aman,dengan harga semurah mungkin serta dengan pemberian informasi yang obyektif. Singkatnya, pola pemakaian obat yang aman dan efektif (cost-effective), efisien dengan good outcome.

Pada pelayanan pengobatan harus dilakukan secara menyeluruh, tenaga kesehatan secara bersama-sama dan mengikutsertakan pasien. Pasien harus diberi tahu penjelasan rejimen terapinya. Pasien perlu menyetujui rencana pengobatannya ( concordance ) sehingga bukan lagi diperintahkan oleh dokter atau perawat dan mematuhinya ( compliance).

Pasien adalah setiap orang yang melakukan konsultasi masalah kesehatannya untuk memperoleh pelayanan kesehatan yang diperlukan, baik secara langsung maupun tidak langsung kepada tenaga kesehatan yang berwenang. Pasien secara khusus dalam kefarmasian adalah penerima pelayanan kefarmasian yaitu setiap orang yang melakukan konsultasi kefarmasian yang berhubungan dengan kesehatannya untuk memperoleh pelayanan yang diperlukan, baik secara langsung maupun tidak langsung kepada apoteker, kewajiban pasien dalam pelayanan kefarmasian diantaranya : memberikan informasi yang jujur, lengkap dan akurat sesuai kemampuan dan pengetahuannya tentang masalah kesehatannya, mematuhi aturan/petunjuk yang disampaikan apoteker, memberi imbalan jasa atas pelayanan yang diterimanya. Dalam Undang-undang tenaga kesehatan No. 36 tahun 2014 Hak warga negara dalam bidang kesehatan pada pasal 4-8 secara berurutan sebagai berikut :

1. Setiap orang berhak atas kesehatan.

2. pasal 5 ada 3 (tiga) ayat (1) Setiap orang mempunyai hak yang sama dalam memperoleh akses atas sumber daya di bidang kesehatan. (2) Setiap orang mempunyai hak dalam memperoleh pelayanan kesehatan yang aman, bermutu, dan terjangkau. (3) Setiap orang berhak secara mandiri dan bertanggung jawab menentukan sendiri pelayanan kesehatan yang diperlukan bagi dirinya.

3. Setiap orang berhak mendapatkan lingkungan yang sehat bagi pencapaian derajat kesehatan.

4. Setiap orang berhak untuk mendapatkan informasi dan edukasi 
tentang kesehatan yang seimbang dan bertanggung jawab.

5. Setiap orang berhak memperoleh informasi tentang data kesehatan dirinya termasuk tindakan dan pengobatan yang telah maupun yang akan diterimanya.

Selain itu masyarakat atau pasien akan mendapatkan Perlindungan Pasien UU No.36 tahun 2009 pasal 56-58 sebagai berikut:

1. Setiap orang berhak menerima atau menolak sebagian atau seluruh tindakan pertolongan yang akan diberikan kepadanya setelah menerima dan memahami informasi mengenai tindakan tersebut secara lengkap.

2. Setiap orang berhak atas rahasia kondisi kesehatan pribadinya yang telah dikemukakan kepada penyelenggara pelayanan kesehatan.

3. Setiap orang berhak menuntut ganti rugi terhadap tenaga kesehatan, dan/atau penyelenggara kesehatan yang menimbulkan kerugian akibat kesalahan atau kelalaian dalam pelayanan kesehatan yang diterimanya.

4. Tuntutan ganti rugi tidak berlaku bagi tenaga kesehatan yang melakukan tindakan penyelamatan nyawa atau pencegahan kecacatan seseorang dalam keadaan darurat.

Kewajiban dan tanggung jawab apoteker Sebagai tenaga Kesehatan dalam UU No.36 tahun 2014 pasal 58- 60 secara berurutan:

a. Memberikan pelayanan kesehatan sesuai dengan Standar Profesi, Standar Pelayanan Profesi, Standar Prosedur Operasional, dan etika profesi serta kebutuhan kesehatan penerima pelayanan kesehatan

b. Memperoleh persetujuan dari penerima pelayanan kesehatan atau keluarganya atas tindakan yang akan diberikan

c. Menjaga kerahasiaan kesehatan penerima pelayanan kesehatan

d. Membuat dan menyimpan catatan dan/atau dokumen tentang pemeriksaan, asuhan, dan tindakan yang dilakukan

e. Merujuk penerima pelayanan kesehatan ke tenaga kesehatan lain yang mempunyai kompetensi dan kewenangan yang sesuai.

f. Tenaga kesehatan yang menjalankan praktik pada fasilitas pelayanan kesehatan wajib memberikan pertolongan pertama kepada penerima pelayanan kesehatan dalam keadaan gawat darurat dan/atau pada bencana untuk penyelamatan nyawa dan pencegahan kecacatan.

g. Tenaga Kesehatan sebagaimana dimaksud pada ayat (1) dilarang menolak penerima pelayanan kesehatan dan/atau dilarang meminta uang muka terlebih dahulu.

h. Mengabdikan diri sesuai dengan bidang keilmuan yang dimiliki

i. Meningkatkan Kompetensi

j. Bersikap dan berperilaku sesuai dengan etika profesi

k. mendahulukan kepentingan masyarakat daripada kepentingan pribadi atau kelompok

1. Melakukan kendali mutu pelayanan dan kendali biaya dalam menyelenggarakan upaya kesehatan.

\section{Pembahasan}

Pasien adalah setiap orang yang melakukan konsultasi masalah kesehatannya untuk memperoleh pelayanan kesehatan yang diperlukan, baik secara langsung maupun tidak langsung kepada tenaga kesehatan yang berwenang. Pasien secara khusus dalam kefarmasian adalah penerima pelayanan kefarmasian yaitu setiap orang yang melakukan konsultasi kefarmasian yang berhubungan dengan kesehatannya untuk memperoleh pelayanan yang diperlukan, baik secara langsung maupun tidak langsung 
kepada apoteker, kewajiban pasien dalam pelayanan kefarmasian diantaranya : memberikan informasi yang jujur, lengkap dan akurat sesuai kemampuan dan pengetahuannya tentang masalah kesehatannya, mematuhi aturan/petunjuk yang disampaikan apoteker, memberi imbalan jasa atas pelayanan yang diterimanya.

Apoteker adalah sarjana farmasi yang telah lulus sebagai apoteker dan telah mengucapkan sumpah/janji apoteker, seorang sarjana farmasi meskipun sudah lulus dari program pendidikan apoteker dan bisa mempunyai sertifikat kompetensi apoteker belum dapat disebut sebagai apoteker sebelum yang bersangkutan disumpah menurut agama dan keyakinannya untuk mengucapkan sumpah/janji apoteker

Kewajiban tenaga kesehatan khususnya farmasi dalam memberikan informasi obat kepada pasien harus memperhatikan beberapa aspek penting seperti tertera dalam Permenkes No.73 Tahun 2016 tentang Standar Pelayanan Kefarmasian di Apotek yaitu tentang Pelayanan Informasi Obat atau PIO

\section{Pelayanan Informasi Obat (PIO)}

Pelayanan Informasi Obat merupakan kegiatan yang dilakukan oleh Apoteker dalam pemberian informasi mengenai Obat yang tidak memihak, dievaluasi dengan kritis dan dengan bukti terbaik dalam segala aspek penggunaan Obat kepada profesi kesehatan lain, pasien atau masyarakat. Informasi mengenai Obat termasuk Obat Resep, Obat bebas dan herbal. Informasi meliputi dosis, bentuk sediaan, formulasi khusus, rute dan metoda pemberian, farmakokinetik, farmakologi, terapeutik dan alternatif, efikasi, keamanan penggunaan pada ibu hamil dan menyusui, efek samping, interaksi, stabilitas, ketersediaan, harga, sifat fisika atau kimia dari Obat dan lain-lain. Kegiatan Pelayanan Informasi Obat di Apotek meliputi:

1. menjawab pertanyaan baik lisan maupun tulisan;

2. membuat dan menyebarkan buletin/brosur/leaflet, pemberdayaan masyarakat (penyuluhan);

3. memberikan informasi dan edukasi kepada pasien;
4. memberikan pengetahuan dan keterampilan kepada mahasiswa farmasi yang sedang praktik profesi;

5. melakukan penelitian penggunaan Obat;

6. membuat atau menyampaikan makalah dalam forum ilmiah;

7. melakukan program jaminan mutu.

Pelayanan Informasi Obat harus didokumentasikan untuk membantu penelusuran kembali dalam waktu yang relatif singkat dengan menggunakan Formulir 6 sebagaimana terlampir. Hal-hal yang harus diperhatikan dalam dokumentasi pelayanan Informasi Obat :

1. Topik Pertanyaan;

2. Tanggal dan waktu Pelayanan Informasi Obat diberikan;

3. Metode Pelayanan Informasi Obat (lisan, tertulis, lewat telepon);

4. Data pasien (umur, jenis kelamin, berat badan, informasi lain seperti riwayat alergi, apakah pasien sedang hamil/menyusui, data laboratorium);

5. Uraian pertanyaan;

6. Jawaban pertanyaan;

7. Referensi;

8. Metode pemberian jawaban (lisan, tertulis, pertelepon) dan data Apoteker yang memberikan Pelayanan Informasi Obat.

Apoteker harus memberikan informasi yang benar, jelas dan mudah dimengerti, akurat, tidak bias, etis, bijaksana, dan terkini. Informasi obat pada pasien sekurangkurangnya meliputi: dosis, efek farmakologi, cara pemakaian obat, cara penyimpanan obat, jangka waktu pengobatan, aktivitas serta makanan dan minuman yang harus dihindari selama terapi.

\section{Hak-hak Pasien menurut Undang-Undang}

Menurut UU kesehatan no 23/1992 dalam Bab Penjelasan dari Pasal 53 ayat 2, hak-hak pasien meliputi:

1. Hak untuk memperoleh informasi

2. Hak untuk memberikan persetujuan

3. Hak atas rahasia kedokteran 


\section{Hak atas pendapat kedua (second opinion)}

Informasi yang berhak diterima pasien antara lain informasi mengenai: penyakit yang diderita, tindakan medik yang hendak dilakukan, informasi obat, kemungkinan penyulit sebagai akibat tindakan tersebut dan tindakan untuk mengatasinya, prognosanya, serta perkiraan biaya pengobatan.

Hak memberikan persetujuan maksudnya bahwa pasien berhak memberikan ijin ataupun menolak atas tindakan yang akan dilakukan oleh dokter sehubungan dengan penyakit yang dideritanya. Pasien juga berhak mengakhiri pengobatan serta perawatan atas tanggung jawab sendiri setelah memperoleh informasi yang jelas mengenai penyakitnya.

Rahasia kedokteran bisa berupa kerahasiaan penyakit yang diderita termasuk data-data medisnya, dan privasinya. Sedangkan hak mendapatkan second opinion (pendapat kedua) memberikan kebebasan kepada pasien untuk berkonsultasi kepada dokter atau tenaga kesehatan kompeten lainnya.

Apabila pasien mendapatkan obat untuk proses terapinya, maka mereka juga berkedudukan sebagai konsumen obat yang mendapatkan hak-haknya menurut Undang-Undang Perlindungan Konsumen. Hak konsumen menurut pasal 5 UU Perlindungan Konsumen adalah:

1. Hak atas kenyamanan, keamanan, dan keselamatan dalam mengkonsumsi barang dan/atau jasa

2. Hak untuk memilih barang dan/atau jasa, serta mendapatkan barang dan/atau jasa tersebut sesuai dengan nilai tukar dan kondisi, serta jaminan yang dijanjikan

3. Hak atas informasi yang benar, jelas, dan jujur mengenai kondisi dan jaminan barang/atau jasa

4. Hak untuk didengar pendapat dan keluhannya atas barang dan/atau jasa yang digunakan

5. Hak untuk mendapatkan advokasi, perlindungan, dan upaya penyelesaian sengketa perlindungan konsumen secara patut
6. Hak untuk mendapat pembinaan dan pendidikan konsumen

7. Hak untuk diperlakukan atau dilayani secara benar, jujur, serta tidak diskriminatif

8. Hak untuk mendapatkan konpensasi, ganti rugi dan/atau penggantian, apabila barang/atau jasa yang diterima tidak sesuai dengan perjanjian atau tidak sebagaimana mestinya.

Pasien yang datang ke apotek untuk membeli obat atau menebus resep, dengan demikian memiliki hak-haknya secara hukum baik sebagai pasien maupun sebagai konsumen. Olehkarena itu sudah menjadi kewajiban dari farmasis di apotek untuk dapat memenuhinya.

\section{Kesimpulan}

Berdasarkan pembahasan diatas maka dapat ditarik kesimpulan bahwa adanya hubungan yang erat antara tenaga kefarmasian dengan pasien. Pentingnya kesadaran mengenai hak dan kewajiban bagi pasien maupun tenaga kefarmasian agar terciptanya pengobatan yang aman, tepat, dan akurat. Dalam dasar hak pasien dan kewajiban tenaga kefarmasian telah diatur dalam suatu peraturan yang mengikat yang harus dipatuhi oleh seluruh pihak. Hal ini bertujuan agar tidak terjadinya medication error atau kesalahan dalam pengobatan khususnya pelayanan informasi obat oleh tenaga kefarmasian. Sehingga penyampaian informasi obat disampaikan dengan penuh tanggung jawab yang telah distujui oleh berbagai pihat yang terkait.

\section{Daftar pustaka}

Saisab, A. M. (2019). PERLINDUNGAN HUKUM BAGI PASIEN AKIBAT APOTEKER YANG LALAI DALAM MEMBERIKAN OBAT-OBATAN. Lex Et Societatis, 7(2).

Siringoringo, V. M., Hendrawati, D., \& Suharto, R. (2017). Pengaturan Perlindungan Hukum Hak-Hak Pasien Dalam Peraturan Perundang-Undangan Tentang Kesehatan Di Indonesia. Diponegoro Law Journal, 6(2), 113. 
Sari, N. (2014). Pemberdayaan Hak Konsumen atas Informasi Obat. Jurnal Media Hukum, 21(2), 16.

PERATURAN MENTERI KESEHATAN REPUBLIK INDONESIA NOMOR 73 TAHUN 2016 TENTANG STANDAR PELAYANAN KEFARMASIAN DI APOTEK

UNDANG-UNDANG No.36 tahun 2014 TENTANG TENAGA KESEHATAN 